REST Journal on Emerging trends in Modelling and Manufacturing
Vol: 7(3), 2021
REST Publisher
ISSN: 2455-4537

\title{
Study of Different Developments of Artificial Intelligence Based Inspection Machine
}

\author{
G. Shanmugasundar, M. Gowtham \\ Department of Mechanical Engineering, Sri Sai Ram Institute of Technology, Chennai, Tamil Nadu, India \\ Email: Shanmugasundar.mech@sairamit.edu.in
}

\begin{abstract}
The purpose of this paper is to describe the survey of the inspection systems and the manufactured component through machine vision system. With this project, mainly the dimension correctness of the manufactured component is tested. The very main goal is to improve the quality of the product. Among the various components of the automatic inspection machine are conveyors, test tables, inspection cameras, reject bins, image processing units, and a monitoring system. Initially, the specimen to be inspected is conveyed by means of conveyors. The inspection camera detects the specimen and takes an image of it for further processing. The image is then processed by the image processing system in terms of pixels. Through the image processing system, the generated image of the specimen is compared with the standard specimen, and the inspection result is projected on the monitor system. The rejected specimen is automatically directed to the rejection bin through nozzle systems. The process is repeated for each specimen. The setup of the machine is bridgetype, so it is possible to inspect more than one piece at a time.
\end{abstract}

Key words: Artificial Intelligence, Machine Vision, Inspection machine

\section{Introduction}

As part of the product development process, a quality inspection machine using artificial intelligence is used to inspect the manufactured product and ensure its dimensional correctness is accuracy. An important success factor for the long-term competitiveness of manufacturing companies is the ability to supply defect-free, high-quality products. Despite the challenges caused by increasing product variety and complexity, and the need for economic manufacturing, comprehensive and reliable quality inspection is often essential. Thus, high inspection volumes turn inspection processes into manufacturing bottlenecks. This technology involves the use of various technologies like machine learning and cloud computing.The proposed allencompassing approach included the handling of the image, image improving, target-oriented information procurement and preparing, demonstrating and show arrangement, as well as the innovative usage. To demonstrate the procedure and benefits of the proposed method, a real industrial application is presented. By employing the various methods, inspection volumes can be reduced significantly, providing economic advantages. As a result of increasing competition, the supply of high-quality products continues to play an important role in ensuring long-term success for a firm. It is essential to ensure a consistently high level of quality for all products in order to guarantee zerodefect delivery and transfer.On top of this, within the ever-growing worldview of personalization, the number of variations and in this way the complexity of review arranging and operation increments tremendously. Therefore, designing inspection processes is an extremely important and economically critical procedure requiring the use of the latest and most sophisticated technologies. Through Industry 4.0, appliances are able to deliver benefits such as personalization, prediction, energy savings, defect reductions, and quality improvement. Cyber-Physical Systems (CPS), the Internet of Things (IoT), cloud computing, and Artificial Intelligence (AI) are included in Industry 4.0. New modalities of human interaction have been enabled by the development of CPS, which constitute a new generation of systems with integrated physical and computational capabilities. An IoT is defined as a key enabler for next-generation advanced manufacturing, describing a global infrastructure that allows physical and virtual objects to be connected through information and communication technologies (ICT). A visual-based approach for fault detection is one of the most common nondestructive testing procedures in the industry. Images captured by the camera or handled by a neural arrange, which is prepared to distinguish and limit the deformity. Once the visual review framework is certain almost sort of issue and its area, it takes after the pre-set informational like sending a notice or executing other operations. In generation of juice bottles amid generation bottles can get harmed which can lead to extra fetched, issues whereas transportation which eventually causes inconvenience for the company. Visual inspection framework based on the computer vision demonstrate recognizes this jumble and informs us in genuine time so that the flawed piece can be prohibited some time recently they reach the ultimate bundling organize. 


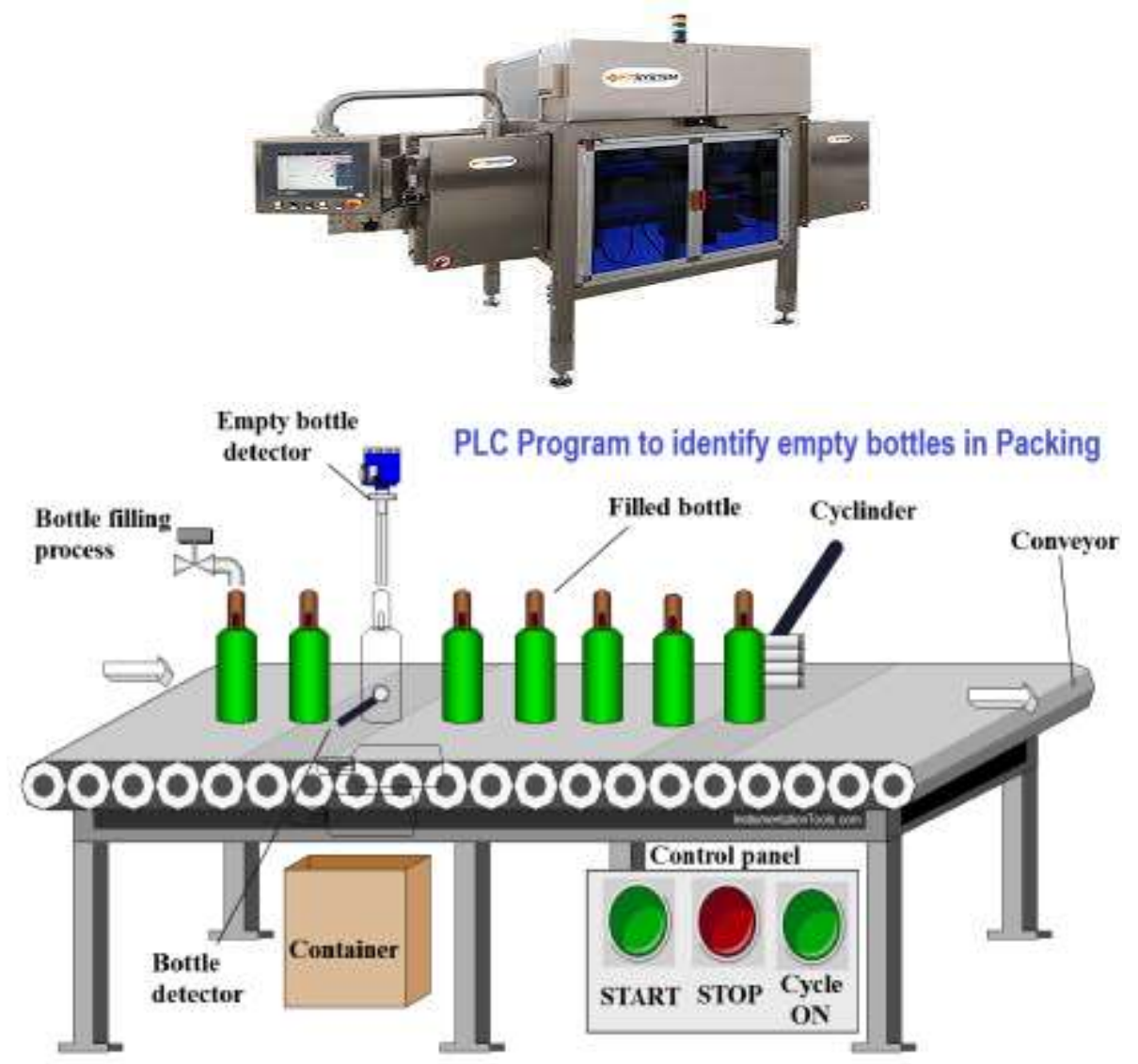

Figure 1. Automated Bottle Inspection Machine

This framework is exceptionally supportive when it comes to security of plant worker, it can be utilized to identify whether the individual is wearing its security measures like gloves, protective cap, goggles, shoes. The neural organize framework is able to dissect this by checking cameras and after that they inform around the infringement. The training of unbiased framework may be a vital perspective within the handle of assessment. A prepared neural arrange gives tall assessment exactness. The organize can be prepared with numerous pictures of diverse objects. The arrange of neural framework depends on the assignment picture detail protest discovery or semantic division pending on how accurately we would like to distinguish deformity. Characterize the errand and prepare the organize so as to detect any deviations from the standard appearance.
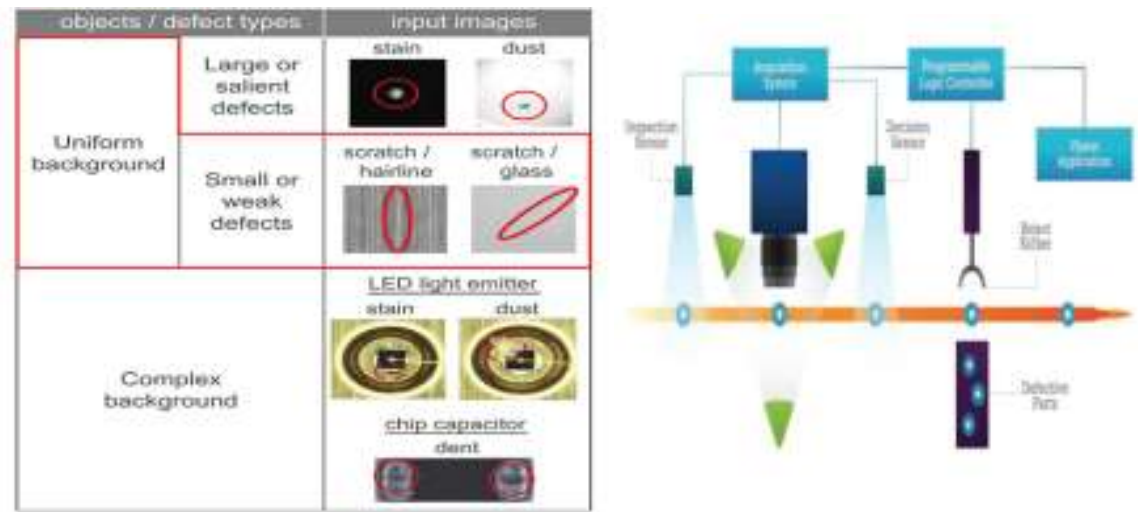

Figure 2. Machine vision system Captured image of the manufactured product

Not as it was on the portion of assessment but Artificial intelligence based inspection has it's applications on street security review as well. Explore on damage discovery of road surfaces utilizing picture preparing strategies has been successfully conducted, accomplishing impressively high discovery correctness. Numerous thinks about as it were centre on the location of the nearness or nonappearance of damage. Be that as it may, in a real-world situation, when the street supervisors from a governing body ought to repair such damage, they ought to clearly get it the sort of damage in arranges to require successful action. In expansion, in many of these past ponders, the researchers procure their claim information utilizing distinctive strategies. Subsequently, there's no uniform street damage dataset accessible direct, driving to the 
nonappearance of a benchmark for road harm discovery. This study makes three commitments to address these issues. To begin with, to the leading of our information, for the primary time, a large-scale street damage dataset is ready. This dataset is composed of 9,053 street damage pictures captured with a Smartphone introduced on a car, with 15,435 occurrences of street surface damage included in these street pictures. In arrange to produce this dataset, a study with 7 municipalities in Japan and obtained street pictures for more than 40 hours. These pictures were captured in a wide assortment of climate and luminance conditions. In each picture, an comment like bounding box speaking to the area and sort of damage. Following, we utilized a state-of-the-art question discovery strategy utilizing convolution neural systems to prepare the harm location show with our dataset, and compared the precision and runtime speed on both, employing a GPU server and a Smartphone. At last, a illustrates the sort of damage can be classified into eight sorts with tall precision by applying the proposed question location strategy. The street damage dataset, our exploratory comes about, and the created Smartphone applications utilized in this think about are freely accessible.

\section{Different Ai- Based Inspection Machine Research}

\begin{tabular}{|c|c|c|c|c|}
\hline $\begin{array}{l}\text { I } \\
\text { si.no }\end{array}$ & Title & Author's & Year & Inference \\
\hline 1. & $\begin{array}{l}\text { Road Damage } \\
\text { Inspection }\end{array}$ & $\begin{array}{l}\text { HiroyaMaeda } \\
\text {,YoshihideSekimeto } \\
\text {,Toshikazu Seto } \\
\text {,Takehiro Kashiyama } \\
\text {,Hiroshi Omata. }\end{array}$ & January 2018 & $\begin{array}{l}\text { They propose the usage of AI for } \\
\text { inspection of roads to ensure the road } \\
\text { safety due to various factors. using a } \\
\text { state-of-the-artobject detection } \\
\text { method using convolutional neural } \\
\text { networks to train the damage } \\
\text { detection model with the dataset, and } \\
\text { compared the accuracy and runtime } \\
\text { speed on both, using a GPU server } \\
\text { and smartphone. }\end{array}$ \\
\hline 2. & $\begin{array}{ll}\text { AI } & \text { Inspection: } \\
\text { Computer } & \text { Vision } \\
\text { For } & \text { Visual } \\
\text { Inspection } & \end{array}$ & $\begin{array}{l}\text { Amruta Mohite } \\
\text {,Atherva Kulkarni } \\
\text {,RutwikChithis } \\
\text {,Swapnil Mane } \\
\text {,Shubham Asabe. }\end{array}$ & January 2021 & $\begin{array}{l}\text { The review paper explains about } \\
\text { computer based visual inspection, } \\
\text { comparison between human and } \\
\text { computer vison system, its } \\
\text { development,improvements and } \\
\text { applications. }\end{array}$ \\
\hline 3. & $\begin{array}{l}\text { Inspection machine } \\
\text { defect detection } \\
\text { based on deep } \\
\text { learning }\end{array}$ & $\begin{array}{l}\text { HanzawaYuki } \\
\text {,IkedaYasuyukiKirut } \\
\text { a ,Manashi } \\
\text {,Hasiwaga Yuki. }\end{array}$ & $\begin{array}{l}\text { OMRON } \\
\text { TECHNICS } \\
\text { Vol.51 September } \\
2019\end{array}$ & $\begin{array}{l}\text { This paper explains us about training } \\
\text { neural networks with help of images } \\
\text { of defects.It uses machine learning } \\
\text { and Artificial intelligence that } \\
\text { imitates the way humans gain certain } \\
\text { knowledge. }\end{array}$ \\
\hline 4. & $\begin{array}{l}\text { Inspection machine } \\
\text { based on Machine } \\
\text { learning and cloud } \\
\text { computing }\end{array}$ & $\begin{array}{l}\text { JochenBoing } \\
\text {,ThorbjornBorggrafe } \\
\text {,GunterBeitinger } \\
\text {,JochenDeuse. }\end{array}$ & $\begin{array}{l}\text { Advanced } \\
\text { Engineering } \\
\text { Informatics, } \\
\text { August } 2020\end{array}$ & $\begin{array}{l}\text { A pre-training type defect-detection } \\
\text { algorithm that could handle a variety } \\
\text { of objects and defect types. Through } \\
\text { the proposed method, we verified that } \\
\text { the algorithm could also handle } \\
\text { objects and defects with unknown } \\
\text { patterns. }\end{array}$ \\
\hline 5. & $\begin{array}{l}\text { Special purpose } \\
\text { Inspection } \\
\text { Machine }\end{array}$ & $\begin{array}{l}\mathrm{AB} \text { Plastomech, } \\
\text { Bangalore. }\end{array}$ & $\begin{array}{l}\text { October } \\
2021\end{array}$ & $\begin{array}{l}\text { This Artificial Intelligence based } \\
\text { inspection machine uses bowl feeder } \\
\text { to take the test specimen to rotating } \\
\text { test table. The machine vision camera } \\
\text { captures the image of specimen and } \\
\text { based on the results the defect is } \\
\text { automatically rejected. }\end{array}$ \\
\hline 6. & $\begin{array}{lr}\text { 3D } & \text { defect } \\
\text { detection } & \text { using } \\
\text { photometric } & \text { stereo } \\
\text { illusion } & \end{array}$ & $\begin{array}{l}\text { Jong Hyuk Lee } \\
\text {,Hyum Min On ,Min } \\
\text { Young Kim. }\end{array}$ & $\begin{array}{l}\text { International } \\
\text { Conference on } \\
\text { Artificial } \\
\text { Intelligence in } \\
\text { Information and } \\
\text { Communication } \\
2019\end{array}$ & $\begin{array}{l}\text { The 3D defect inspection involves the } \\
\text { use of laser sensors to ensure } \\
\text { 3Dimensional inspection of the work } \\
\text { piece and also the use of photometric } \\
\text { stereo illusion systems. }\end{array}$ \\
\hline
\end{tabular}




\begin{tabular}{|c|c|c|c|c|}
\hline $\begin{array}{l}\text { I } \\
\text { si.no }\end{array}$ & Title & Author's & Year & Inference \\
\hline 7. & $\begin{array}{l}\text { Quality control } \\
\text { inspection } \\
\text { opportunities using } \\
\text { deep learning }\end{array}$ & $\begin{array}{l}\text { VladimirsSatrevics } \\
\text {,GundarsKulikovskis } \\
\text {,Oskars Oss. }\end{array}$ & $\begin{array}{lr}24 \text { th World } & \text { Multi- } \\
\text { Conference } & \text { on } \\
\text { Systemics, } & \\
\text { Cybernetics } & \text { and } \\
\text { Informatics (WMSCI } \\
2020)\end{array}$ & $\begin{array}{l}\text { To meet industry standard quality } \\
\text { inspectors in manufacturing firms } \\
\text { inspect product quality usually after } \\
\text { the product is manufactured in order } \\
\text { to reduce time consuming inspection. }\end{array}$ \\
\hline 8. & $\begin{array}{l}\text { Fracture detection } \\
\text { using machine } \\
\text { vision and neural } \\
\text { network }\end{array}$ & Sarthak J Shetty. & January 2019 & $\begin{array}{l}\text { They propose the usage of OpenCV } \\
\text { an open source computer vision } \\
\text { framework developed by Google.to } \\
\text { accomplish the task of detection and } \\
\text { prediction of presence of surface } \\
\text { defects such as fracture of gears }\end{array}$ \\
\hline 9. & $\begin{array}{lr}\text { Machine } & \text { Vision } \\
\text { application } & \text { in } \\
\text { Industrial } & \\
\text { application } & \end{array}$ & Diego Gonzales. & January 2021 & $\begin{array}{l}\text { They propose that machine vision is } \\
\text { the technology used to provide } \\
\text { imaging based automatic inspection } \\
\text { and analysis for such application as } \\
\text { automatic inspection, process control } \\
\text { and robot guidance. }\end{array}$ \\
\hline 10. & $\begin{array}{l}\text { Automatic } \\
\text { Inspection System } \\
\text { using machine } \\
\text { vision }\end{array}$ & $\begin{array}{l}\text { U.S.Khan } \\
\text {,M.A.Khan ,J.Iqbal. }\end{array}$ & $\begin{array}{l}\frac{\text { 34th Applied }}{\text { Imagery and }} \\
\frac{\text { Pattern }}{\text { Recognition }} \\
\frac{\text { Workshop }}{(\text { AIPR'05) }}\end{array}$ & $\begin{array}{l}\text { Machine vision system integrated } \\
\text { electronic components with software } \\
\text { systems to imitate a variety of human } \\
\text { functions. The technique discussed in } \\
\text { this paper inspects on basic pixel level } \\
\text { image processing. }\end{array}$ \\
\hline 11. & $\begin{array}{lr}\text { Bone fracture } \\
\text { Detection and } \\
\text { Classification } \\
\text { using deep } \\
\text { learning }\end{array}$ & $\begin{array}{l}\text { D.P. Yadav, Sandeep } \\
\text { Rathor }\end{array}$ & $\begin{array}{l}\text { 2020 International } \\
\text { Conference on Power } \\
\text { Electronics \& IoT } \\
\text { Applications } \\
\text { Renewable Energy and } \\
\text { its Control (PARC) } \\
\text { Feb. } 2020\end{array}$ & $\begin{array}{l}\text { The fracture in bone mainly occurs } \\
\text { due to bad fall. The usage of MRI and } \\
\text { X-rays. The purpose of the project is } \\
\text { to involving neural network } \\
\text { technology to detect and monitor } \\
\text { cracks in bones a deep neural network } \\
\text { model has been developed to classify } \\
\text { the fracture and healthy bone has been } \\
\text { proposed. }\end{array}$ \\
\hline 12. & $\begin{array}{lr}\text { Bone } & \text { Fracture } \\
\text { detection } & \text { using } \\
\text { ML and } & \text { Digital } \\
\text { Geometry. } & \end{array}$ & $\begin{array}{lr}\text { Ashosh } & \text { Sharma, } \\
\text { Abisek } & \text { Mishra, } \\
\text { Aashi Bansal }\end{array}$ & September 2021 & $\begin{array}{l}\text { The usage of orthopedic X-ray } \\
\text { imaging for bone fracture detection } \\
\text { and deployment of Machine learning } \\
\text { techniques to detect and cure bone } \\
\text { fractures. }\end{array}$ \\
\hline 13. & $\begin{array}{l}\text { Artificial } \\
\text { Intelligence } \\
\text { application in bone } \\
\text { fracture detection }\end{array}$ & $\begin{array}{l}\text { Ahmed AlGhaiti } \\
\text {,Sultan Al Maskari . }\end{array}$ & March 2021 & $\begin{array}{l}\text { They proposed the use of } \\
\text { convolutional neural network, deep } \\
\text { Learning, machine learning, Artificial } \\
\text { Intelligence to help clinicians to } \\
\text { monitor the fractured bone. }\end{array}$ \\
\hline
\end{tabular}

\section{Conclusion}

The Artificial intelligence based inspection also has applications in weld joints testing, internal defect analysis and even in structural analysis as well .The application of artificial intelligence are for more exceeding .The future scope of the project involves three dimensional inspection which can be used in automobile part inspection, involving the use of camera's in all three dimensions and even converting the captured image into 3D models which could be processed and updated based on the requirements of the future . 


\section{References}

1. Hoai Phuong Nguyen, Thi Phuong Hoang, Huy Hoang Nguyen, "A deep learning based fracture detection in arm bone X-ray images", Multimedia Analysis and Pattern Recognition (MAPR) 2021 International Conference on, pp. 1-6, 2021

2. Moallem, P.; Serajoddin, A.; Pourghassem, H. Computer vision-based apple grading for golden delicious apples based on surface features. Inf. Process. Agric. 2017, 4, 33-40.

3. Wang, J.; Fu, P.; Gao, R.X. Machine vision intelligence for product defect inspection based on deep learning and Hough transform. J. Manuf. Syst. 2019, 51, 52-60.

4. Shanmugamani, R.; Sadique, M.; Ramamoorthy, B. Detection and classification of surface defects of gun barrels using computer vision and machine learning. Measurement 2015, 60, 222-230

5. Krishnan, G. S., Shanmugasundar, G., Vanitha, M., Pradhan, R., \& Sivam, S. P. S. S. (2021). Performance analysis on mechanical/morphological properties of ramie-kenaf hybrid polymer composites. 2nd international conference on advanced materials behaviour and characterization: ICAMBC_2021, 2417. https://doi.org/10.1063/5.0072635.

6. Pradhan, R., Shanmugasundar, G., Vanitha, M., Krishnan, G. S., \& Sivam, S. P. S. S. (2021). A critical investigation on the performance of bael biodiesel in CI engine. 2nd international conference on advanced materials behaviour and characterization: ICAMBC_2021, 2417. https://doi.org/10.1063/5.0072637.

7. Sai Krishnan, G., Pravin Kumar, J., Shanmugasundar, G., Vanitha, M., \& Sivashanmugam, N. (2020). Investigation on the alkali treatment of Demostachya Bipinnata fibers for automobile applications-A green composite. Materials Today: Proceedings, 43, 828-831. https://doi.org/10.1016/j.matpr.2020.06.530.

8. Sai Krishnan, G., Shanmugasundar, G., Vanitha, M., \& Sivashanmugam, N. (2020). Mechanical Properties of Chemically Treated Banana and Ramie Fibre Reinforced Polypropylene Composites. IOP Conference Series: Materials Science and Engineering, 961(1). https://doi.org/10.1088/1757-899X/961/1/012013.

9. Sai Krishnan, G., Shanmugasundar, G., Vanitha, M., Srinivasan, S., \& Suresh, G. (2020). Investigation on the Mechanical and Morphological Properties of Red banana/Ramie Fiber vinyl ester composites. IOP Conference Series: Materials Science and Engineering, 961(1). https://doi.org/10.1088/1757-899X/961/1/012015.

10. Sai Krishnan, G., Shanmugasundar, Pradhan, R., \& Loganathan, G. B. (2020). Investigation on Mechanical Properties of Chemically Treated Banana and Areca Fiber Reinforced Polypropylene Composites. https://doi.org/10.1007/978-981-15-7827-4_27.

11. Shanmugasundar, G., Dharanidharan, M., Vishwa, D., Jayaprakash, A., \& Abimanyu, P. (2020). Design and Finite Element Analysis of Prosthetic Hand Controlled by Wireless Gestures for Differently-abled People. IOP Conference Series: Materials Science and Engineering, 923(1). https://doi.org/10.1088/1757-899X/923/1/012019.

12. Shanmugasundar, G., Dharanidharan, M., Vishwa, D., \& Sanjeev Kumar, A. P. (2020). Design, analysis and topology optimization of connecting rod. Materials Today: Proceedings, 46, 3430-3438. https://doi.org/10.1016/j.matpr.2020.11.778.

13. Shanmugasundar, G., Fenneth Moses, G., Jayachandran, S., Rathnavel Subramanian, V. D., \& Rajagopalan, R. (2020). Design and fabrication of solar powered multi-purpose agricultural vehicle with iot control. Journal of Advanced Research in Dynamical and Control Systems, $12(7$ Special Issue). https://doi.org/10.5373/JARDCS/V12SP7/20202306.

14. Shanmugasundar, G., Jagadeeshwar, P., Adithya, S., Nagappan, V., \& Bhaskar, M. (2019). Design, fabrication and analysis of personal vacuum assisted climber. Journal of Physics: Conference Series, 1362(1). https://doi.org/10.1088/1742-6596/1362/1/012057.

15. Shanmugasundar, G., Karthikeyan, B., Santhosh Ponvell, P., \& Vignesh, V. (2019). Optimization of process parameters in TIG welded joints of AISI 304L -austenitic stainless steel using taguchi's experimental design method. Materials Today: Proceedings, 16, 1188-1195. https://doi.org/10.1016/j.matpr.2019.05.213.

16. Shanmugasundar, G., \& Sivaramakrishnan, R. (2015). Computer aided modelling and simulation of a generic robot for inspection. International Journal of Applied Engineering Research, 10(24), 44049-44056.

17. Shanmugasundar, G., \& Sivaramakrishnan, R. (2016). Design and analysis of a newly developed seven degree of freedom robot for inspection. International Journal of Control Theory and Applications, 9(24), 393-402.

18. Shanmugasundar, G., \& Sivaramakrishnan, R. (2012). Software Development for an Inverse Kinematics of SevenDegrees of Freedom Newly Designed Articulated Inspection Robot. International Journal of Computer Applications, 58(18). https://doi.org/10.5120/9384-3858.

19. Shanmugasundar, G., Sivaramakrishnan, R., \& Balasubramani, S. (2017). Method of Trajectory Generation of a Generic Robot using Bresenham's Circle Algorithm. Indian Journal of Science and Technology, 9(48). https://doi.org/10.17485/ijst/2016/v9i48/108476.

20. Shanmugasundar, G., Sivaramakrishnan, R., Meganathan, S., \& Balasubramani, S. (2019). Structural optimization of an five degrees of freedom (T-3R-T) robot manipultor using finite element analysis. Materials Today: Proceedings, 16, 1325-1332. https://doi.org/10.1016/j.matpr.2019.05.231.

21. Shanmugasundar, G., Sivaramakrishnan, R., \& Rajmohan, M. (2015). Computer aided simulation for workspace plot of a newly designed inspection robot. 2014 IEEE International Conference on Computational Intelligence and Computing Research, IEEE ICCIC 2014. https://doi.org/10.1109/ICCIC.2014.7238470. 
22. Shanmugasundar, G., Sivaramakrishnan, R., Sridhar, R., \& Rajmohan, M. (2015). Computer Aided Modelling and Static Analysis of an Inspection Robot. Applied Mechanics and Materials, $766-767$. https://doi.org/10.4028/www.scientific.net/amm.766-767.1055.

23. Shanmugasundar, G., Sivaramakrishnan, R., \& Venugopal, S. (2013). Modeling, design and static analysis of seven degree of freedom articulated inspection robot. Advanced Materials Research, 655-657, $1053-1056$. https://doi.org/10.4028/www.scientific.net/AMR.655-657.1053.

24. Shanmugasundar, G., Sri Sabarinath, S., Ramesh Babu, K., \& Srividhya, M. (2020). Analysis of occupational health and safety measures of employee in material manufacturing industry using statistical methods. Materials Today: Proceedings, 46, 3259-3262. https://doi.org/10.1016/j.matpr.2020.11.296.

25. Shanmugasundar, G., Vanitha, M., Babu, L. G., Suresh, P., Mathiyalagan, P., Krishnan, G. S., \& Makos, M. (2020e). Fabrication and analysis of mechanical properties of PVC/Glass fiber/graphene nano composite pipes. Materials Research Express, 7(11). https://doi.org/10.1088/2053-1591/abc277.

26. Shanmugasundar, G., Vanitha, M., Babu, L. G., Suresh, P., Mathiyalagan, P., Krishnan, G. S., \& Makos, M. (2020f). Fabrication and analysis of mechanical properties of PVC/Glass fiber/graphene nano composite pipes. Materials Research Express, 7(11). https://doi.org/10.1088/2053-1591/abc277.

27. Shanmugasundar, G., Vanitha, M., Sai Krishnan, G., \& Srinivasan, S. (2020). Investigation on the mechanical properties of newly modified polymeric fiber for structural applications. Materials Today: Proceedings, 46, 34393443. https://doi.org/10.1016/j.matpr.2020.11.781.

28. Shanmugasundar, G., Yokesh, R., Yuvaranjith, S., Barath, R., \& Balasubramanian, S. (2020). Design and fabrication of intelligent gas stove for indian women safety. International Journal of Pharmaceutical Research, 12(2), 819-823. https://doi.org/10.31838/IJPR/2020.12.02.0126.

29. Sridhar, R., Shanmugasundar, G., \& Srithar, A. (2016). A Geometrical Modular Design for Handling of LPG Cylinders using Nested Kinematic Robotic Gripper. Indian Journal of Science and Technology, 9(48). https://doi.org/10.17485/ijst/2016/v9i48/108474 